\title{
PERBANDINGAN TEKNIK RELAKSASI OTOT PROGRESIF DAN AKUPRESUR TERHADAP DISMENORE PADA MAHASISWI FKP UNIVERSITAS RIAU
}

\author{
Cica Kristina ${ }^{1}$, Oswati Hasanah ${ }^{2}$, Ririn Muthia Zukhra ${ }^{3}$ \\ ${ }^{1,2,3}$ Fakultas Keperawatan, Universitas Riau \\ Email : cica_ristina@yahoo.com
}

Diterima: Maret 2021, Diterbitkan: Juni 2021

\begin{abstract}
ABSTRAK
Angka kejadian dismenore di dunia sangat tinggi yaitu $16.8-81 \%$ perempuan di setiap Negara mengalami dismenore dan terkhusus berdampak pada remaja usia akhir (mahasiswi) yang menyebabkan terganggunya aktivitas sehari-hari. Jika seorang mahasiswi mengalami dismenore, aktivitas perkuliahan terganggu dan tak jarang hal ini membuat mereka tidak masuk kuliah. Intervensi yang tepat dan efektif untuk mengatasi dismenore harus dilakukan untuk mengurangi intensitas dismenore. Tujuan penelitian ini untuk mengidentifikasi perbedaan efektivitas relaksasi otot progresif dan akupresure terhadap penurunan intensitas dismenore dengan alat ukur Numeric Rating Scale (NRS). Penelitian ini mengunakan rancangan quasi eksprimental dengan two group comparison pretest-posttest. Sampel penelitian yaitu mahasiswi yang mengalami dismenore sebanyak 38 orang yang terbagi 2 kelompok yaitu kelompok relaksasi otot progresif dan akupresur yang mengunakan teknik purposive sampling. Analisa data mengunakan uji Wilcoxon \& Mann Whitney. Hasil penelitian menunjukkan terapi akupresur dan relaksasi otot progresif dapat menurunkan intensiitas nyeri dengan hasil $p$-value $0.001<\alpha(0.05)$. Simpulan penelitian ini ialah terapi akupresur lebih signifikan mengurangi intensitas nyeri dismenore dibandingkan relaksasi otot progresif.

Kata Kunci: Akupresur, Dismenore, Relaksasi otot progresif
\end{abstract}

\section{ABSTRACT}

The incidence of dysmenorrhea in the world is very large namely 16.8-81\% of women in each country experience dysmenorrhea and the impactoon adolescents of campus age which causes distruption of daily activities. If a student experiences dysmenorrhea, the student's learning activities at campus are disrupted and often this makes them absent from campus. Therefore, an appropriate and affective intervention is required. This study aims to identify the differences of effectiveness of progressive muscle relaxation and acupressure to relieve dysmenorrhea among teenegers. The study used the design quasy expo with the two groups pre-post design test. The study sample is that of a student who was diagnosed with a dismenorrhea of 38 people who split into two groups, a progressive muscle relaxation group and an acupressure sampling. The data analysis Uses the wilcoxon test and mann Whitney. Studies show acupressure therapy and progressive muscle relaxation can lower the intensity of pain by p-value $0.001<\alpha(0.05)$. The conclusion of the study is that acupuncture therapy reduces the intensity of dysmenrhea pain more than progressive muscle relaxation.

Keywords: Acupressure, Dysmenorrhea, Progressive muscle relaxation

\section{PENDAHULUAN}

Perbedaan penelitian ini dengan penelitian yang lain adalah pada proses penelitian yang menggunakan Desain Quasy Ekspriment dengan rancangan Two Group Pretest-Posttest with Two Comparative Study yang bertujuan membandingkan antara terapi relaksasi otot progresif dan akupresur. Proses penelitian ini menggunakan skala Numeric Rating Scale (NRS) untuk mengukur intensitas nyeri dismenore seluruh mahasiswi yang aktif pada Fakultas Keperawatan Universitas Riau yang mengalami dismenore. 
Dysmenorrhea atau Dismenore berasal dari bahasa Yunani Kuno yang terdiri dari 3 suku kata yakni Dys artinya sulit, nyeri atau abnormal, meno artinya bulan dan rrhea artinya aliran. Maka, dismenore dapat diartikan sebagai aliran haid yang sulit dan bersifat kolik pada perut bagian bawah terkhusus menjalar kebagian punggung atau permukaan dalam paha terjadi baik itu sebelum, selama atau sesudah haid (Ayu, 2019).

Gangguan ini biasanya mulai terjadi pada 24 jam sebelum terjadinya perdarahan haid atau dapat juga dirasakan pada saat awal haid yang akan memuncak seiring dengan banyaknya aliran darah haid yang keluar. Hampir rata-rata perempuan yang dismenore mengalami rasa tidak nyaman seperti rasa tidak enak di perut bagian bawah disertai dengan mual, mudah marah, pusing, sakit kepala, kelelahan bahkan bisa pingsan (Anurogo \& Wulandari, 2011).

Dismenore merupakan kondisi yang normal dialami oleh beberapa perempuan yang mengalami haid, dikarenakan ketidakseimbangan progesterone dalam darah yang menganggu selama fase luteal pada siklus haid, mengakibatkan peningkatan prostaglandin terutama E2 (Dinoprostone) dan F2 alfa dalam jumlah yang tinggi pada fase awal haid, yang berdifusi ke dalam jaringan endometrial yang menyebabkan kontraksi tonus miometrium dan uterus yang kuat serta mampu menyempitkan pembuluh darah, sehingga mengakibatkan terjadinya iskemia, perdarahan dan rasa nyeri (Anurogo \& Wulandari, 2011). Akan tetapi, menurut Pavithra, et al, (2020) dismenore menjadi penting untuk ditangani jika terbukti menimbulkan beberapa dampak negatif seperti merasa lemah dan lelah.

Dismenore terbagi menjadi 2 jenis yaitu dismenore primer dan sekunder. Dismenore primer merupakan nyeri haid yang dijumpai tanpa ada kelainan pada alatalat genetalia yang nyata dimana tubuh mengalami proses fisiologis yang normal, sedangkan dismenore sekunder merupakan nyeri haid yang disebabkan kelainan ginekologis seperti terjadinya endometriasis (Sukarni \& Wahyu, 2013).

Pada umumnya, dismenore yang sering terjadi pada remaja dan dewasa awal yaitu dismenore primer. Secara proses fisiologis, dismenore primer terjadi karena adanya pelepasan prostaglandin yaitu zat kimia yang memicu kram, yang terletak di dalam darah sehingga menyebabkan meningkatnya aktivitas di dalam uterus. Jika kadar prostaglandin tersedia dalam jumlah sedikit dapat menyebabkan kram ringan, tetapi apabila dalam jumlah yang besar dapat menyebabkan mual, muntah, sakit kepala, sakit punggung, diare dan kram yang parah (Anurogo \& Wulandari, 2011). Kadar hormon prostaglandin pada perempuan yang sedang dismenore meningkat sekitar 5-13 kali dibandingkan perempuan yang tidak dismenore (Sukarni \& Wahyu, 2013).

Menurut World Health Organization (WHO) dalam Penelitian Hasanuddin (2019), angka kejadian dismenore cukup tinggi di seluruh dunia.Rata-rata insidensi terjadinya dismenore pada wanita muda antara $16.8-81 \%$. Rata-rata di Negaranegara Eropa terjadi pada $45-97 \%$ dengan prevalensi terendah di Bulgaria 8,8\% dan tertinggi mencapai $94 \%$ di Finlandia dengan prevalensi tertinggi sering ditemui pada remaja yang diperkirakan terjadi antara 20-90\%. Sedangkan di Indonesia sendiri, banyak fenomena yang mengalami dismenore tidak melaporkan atau tidak berkunjung ke dokter dengan alasan banyak yang cenderung meremehkan kondisi tersebut sehingga membuat data kasus tidak dapat dipastikan secara mutlak (Anurogo \& Wulandari, 2011) dimana kejadian nyeri haid yang tercatat sebanyak $64,25 \%$ yang terdiri dari 54,89\% mengalami nyeri haid primer sedangkan 9,36\% mengalami nyeri haid sekunder (Putinah, 2019). Untuk angka kejadian dismenore di Riau pernah diteliti oleh Putri (2012), pada remaja putri dari rentang usia 15-16 tahun di kecamatan Bangko Kabupaten Rokan Hilir didapatkan prevalensi dismenore sebesar $95,7 \%$. 
Dampak dismenore sangat merugikan bagi yang mengalaminya, seperti dapat mengakibatkan terganggunya aktivitas sehari-hari, akademis, sosial dan olahraga. Menurut Anurogo dan Wulandari (2011) Nyeri haid memaksa penderita untuk istirahat dan meninggalkan aktivitas rutin sehari-harinya, selama beberapa jam bahkan bisa dalam beberapa hari dan memerlukan obat serta penanganan yang khusus.

Penanganan dismenore terbagi menjadi farmakologis dan non farmakologis.Secara farmakologis nyeri haid ini dapat ditangani dengan diberikan obat analgetik Non Steroid Anti Inflamasi Drugs (NSAID) seperti ibuprofen, naproxen, paracetamol, dan asam mefenamat yang merupakan metode paling umum digunakan untuk menghilangkan nyeri (Ratnawati, 2018).

Menghilangkan nyeri dengan cara mengkonsumsi obat-obatan sangatlah ampuh, akan tetapi cara ini dapat mengakibatkan timbulnya efek samping jika dikonsumsi secara terus menerus dalam jangka waktu lama. Metode pereda nyeri non farmakologis biasanya mempunyai risiko yang sangat rendah, meskipun tindakan tersebut bukan merupakan pengganti untuk obat-obatan, tetapi tindakan tersebut mungkin diperlukan atau sesuai untuk mempersingkat episode nyeri yang berlangsung hanya dalam beberapa detik/menit (Smeltzer \& Bare, 2015).

Secara non farmakologis dapat dilakukan diantaranya menggunakan teknik relaksasi, latihan pernafasan, pergerakan dan perubahan posisi, massage, hidroterapi, terapi panas/dingin, musik, guided imagery, akupressure, dan aromaterapi. Dalam hal ini, terapi non farmakologis yang menarik perhatian untuk mengatasi nyeri dismenore yaitu teknik relaksasi dan akupresur. Teknik Relaksasi salah satunya yang dapat dilakukan adalah dengan melakukan tindakan relaksasi otot progresif, dimana dapat menurunkan rasa nyeri dengan cara merilekskan ketegangan otot yang menunjang nyeri (Smeltzer \& Bare, 2015).
Relaksasi otot progresif merupakan suatu keterampilan yang dapat dipelajari dan digunakan untuk mengurangi ketegangan sehingga menimbulkan rasa nyaman tanpa tergantung pada sesuatu/subjek diluar dirinya.Teknik relaksasi otot progresif merupakan tindakan mengidentifikasi serta memusatkan perhatian pada suatu aktivitas otot yang tegang kemudian merilekskan ototnya (Anurogo \& Wulandari, 2011). Pasien diajarkan merapatkan kelompok otot (seperti otot wajah), menahan tegangan selama beberapa detik, dan merileksasikan kelompok otot secara lengkap, serta mengulangi aktivitas tersebut untuk semua bagian tubuh (Lemone, Burke, \& Bauldoff, 2016).

Penelitian terkait yang mendukung tentang relaksasi otot progresif adalah penelitian yang dilakukan oleh Dewi, Siti, dan Khairiyah (2018) dengan hasil penelitian membuktikan adanya pengaruh relaksasi otot progresif terhadap penurunan skala nyeri punggung bagian bawah pada ibu hamil trimester III. Penelitian terkait yang mendukung lainnya adalah penelitian yang dilakukan Akbar, Putria, dan Afriyanti (2012) dengan hasil penelitian membuktikan bahwa relaksasi otot progresif dapat menurunkan nyeri dismenore pada remaja. Sejalan dengan penelitian yang dilakukan Livolina, Friska, dan Olivia (2014) menunjukkan adanya pengaruh relaksasi otot progresif terhadap penurunan intensitas nyeri menstruasi.

Pada pengobatan tradisional Cina, banyak terapi yang dapat meringankan nyeri dismenore salah satunya menggunakan teknik akupresur (Ody, 2008). Akupresur (teknik tekan jari) merupakan proses penekanan di suatu titik tertentu pada bagian tubuh manusia yang bertujuan untuk menghilangkan gejala atau penyakit pada seseorang (Master, 2020).

Secara empiris terapi akupresur terbukti dapat membantu meningkatkan secara alami hormon endorphin di otak yang dapat membantu mengurangi rasa nyeri dismenore (Iwan \& Hartono, 2012). 
Endorphin diproduksi oleh tubuh di dalam darah dan opioid peptide endogenous di dalam susunan syaraf pusat, yang selanjutnya memberi perintah pada sistem endokrin untuk melepaskan endorfinnya yang berfungsi sebagai pembunuh rasa nyeri pada saat haid (Widyaningrum, 2013).

Beberapa titik yang terbukti dapat digunakan untuk penanganan dismenore adalah titik yang biasa digunakan untuk mengatasi masalah ginekologis yang meliputi titik Sanyinjiao (SP6), Hoku (L14), Taichong (LR3), Liver (CO12), Ginjal (CO10) dan titik Endokrin (CO18). Titik Yintang merupakan titik istimewa yang terletak pada bagian tengah kedua alis mata yang berfungsi untuk meningkatkan relaksasi tubuh sedangkan titikLR3 (Taichong) terletak pada punggung kaki yaitu disela-sela tulang antara jari jempol dan telunjuk kaki yang berfungsi sebagai relaksasi dan analgesik (Alamsyah, 2009).

Penelitian terbaru yang mendukung tentang akupresur adalah penelitian yang dilakukan Hasanah, Lestari, Novayelinda, dan Deli (2020) dimana dilakukan terapi akupresur pada tiga titik kombinasi yaitu LR 3, Li4 dan titik Yintang terjadi penurunan intensitas nyeri sebesar 3.13 point. Penelitian terkait yang mendukung lainnya adalah penelitian yang dilakukan oleh Tepi, Situmorang, dan Yulianti (2019) dimana dilakukan akupresur pada titik SP6 dapat menurunkan intensitas nyeri dismenore sebesar 2.12 point pada remaja putri di Kota Bengkulu. Sejalan dengan penelitian yang dilakukan oleh Julianti, Hasanah, dan Erwin (2014) dimana dilakukan akupresur pada titik LI4 dan titik PC6 terjadi penurunan intensitas nyeri sebesar 1.85 point.

Berdasarkan studi pendahuluan yang telah dilakukan terhadap 164 orang mahasiswi di Fakultas Keperawatan Universitas Riau didapati $73.17 \%$ mahasisiwi yang mengalami dismenore setiap bulannya, kemudian peneliti melakukan wawancara terhadap 10 mahasiswi yang mengalami dismenore melalui aplikasi Whatshapp pada tanggal 07-09 September 2020.

Hasil wawancara didapatkan bahwa 5 orang mahasiswi yang mengalami dismenore belum pernah melakukan terapi relaksasi otot progresif dan akupresur dalam menurunkan nyeri dismenore, 4 orang mengatakan hanya mengkonsumsi obat anti steroid dan 6 orang lainnya melakukan tindakan seperti pakai minyak angin, minum air hangat dan hanya didiamkan saja.

\section{METODE}

Jenis desain penelitian yang digunakan adalah quasy ekspriment dengan rancangan penelitian two group pretestposttest with two comparative study. Rancangan ini bertujuan untuk membandingkan hasil yang didapat sebelum dan sesudah diberi terapi relaksasi otot progresif dan akupresur.

Pengambilan sampel dilakukan dengan purposive sampling sesuai dengan kriteria inklusi yaitu, pada masa remaja akhir (18-26 tahun), memiliki Handphone dengan aplikasi Whatshaap, mengalami intensitas nyeri sedang (4-6), serta tidak mengkonsumsi analgetik, dengan jumlah sampel sebanyak 38 responden yang terdiri dari 19 responden sebagai kelompok relaksasi otot progresif dan 19 sebagai kelompok akupresur.

Pengukuran intensitas nyeri dilakukan dengan menggunakan numeric rating scale (NRS).Dimana NRS merupakan skala yang didasari pada skala angka 1-10 untuk menggambarkan intensitas nyeri yang dirasakan, dimana skala NRS diklaim lebih mudah dipahami oleh seseorang (Potter dan Perry, 2010).

Pada kelompok terapi relaksasi otot progresif, peneliti melakukan 14 gerakan yang melibatkan otot tangan, kaki, dahi, mata, otot bibir, rahang, dada dan leher, sedangkan pada kelompok akupresur, peneliti melakukan terapi pada titik yintang dan titik taichong (LR3), dimana masingmasing terapi dilakukan sebanyak empat sesi selama 2 hari yang dilakukan pada hari 
pertama dan hari kedua haid. Kedua terapi ini dilakukan setiap hari dengan masingmasing terapi sebanyak 2 sesi/hari dengan 5 menit/sesi.

\section{HASIL}

Berdasarkan hasil penelitian yang telah dilakukan, maka diperoleh hasil sebagai berikut:

Tabel 1

Distribusi Karakteristik Berdasarkan Umur, Suku, dan Siklus Haid

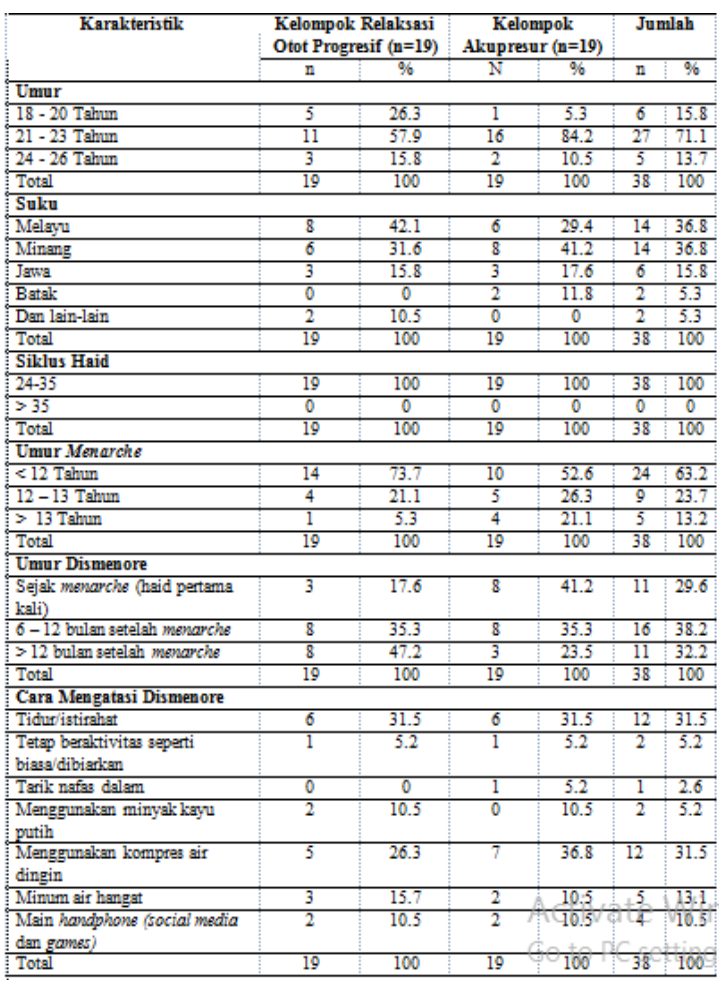

Berdasarkan tabel 1 dapat dilihat dari 38 orang responden yang diteliti, distribusi responden menurut umur mayoritas berusia 21-23 tahun (71.1\%), suku kedua kelompok mayoritas adalah suku Melayu dan suku Minang yang jumlahnya sama banyak masing-masing sebesar $36.8 \%$, serta secara keseluruhan responden dalam penelitian ini memiliki siklus haid dalam rentang yang normal $(100 \%)$ dengan mayoritas responden mengalami menarche berusia kurang dari 12 tahun $(63.2 \%)$ dimana mengalami dismenore pada 6-12 bulan setelah menarche (38.2\%). Cara mengatasi haid yang dilakukan oleh responden mayoritas menggunakan kompres air dingin dan tidur yang jumlahnya sama banyak masingmasing (31.5\%).

Tabel 2

Perbandingan Intensitas Nyeri (Posttest) Pada Kelompok Terapi Relaksasi Otot Progresif dan Kelompok Terapi Akupresur

\begin{tabular}{|c|c|c|c|c|c|}
\hline \multirow[t]{2}{*}{ Kelompol } & \multirow[t]{2}{*}{$n$} & \multicolumn{2}{|c|}{ Posttest } & \multirow[t]{2}{*}{ Mean Rank } & \multirow[t]{2}{*}{ p-value } \\
\hline & & Mean & SD & & \\
\hline Relaksasi otot progresif & 19 & 3.42 & 1.121 & 15.34 & 0.001 \\
\hline Aluppesur & 19 & 3.11 & 1.197 & 23.66 & \\
\hline
\end{tabular}

Berdasarkan tabel 2 dapat dilihat rata-rata intensitas nyeri setelah dilakukan tindakan pada kelompok terapi relaksasi otot progresif adalah sebesar 3.42 poin sedangkan rata-rata intensitas nyeri pada kelompok terapi akupresur adalah 3.11poin dengan p-value $0.001<\alpha(0.05)$ sehingga dapat disimpulkan terdapat perbedaan ratarata intensitas nyeri dismenore setelah dilakukan tindakan terapi relaksasi otot progresif dan akupresur.

Tabel 3

Rata-Rata (Mean) Intensitas Nyeri

Sebelum dan Sesudah Diberikan

Intervensi Pada Kelompok Terapi

Relaksasi Otot Progresif dan Akupresur

\begin{tabular}{|l|c|c|c|c|}
\multicolumn{1}{|c|}{ Intensitas nyeri } & Mean & SD & Mm & Max \\
\hline Pretest Relaksasi otot progresif & 4.89 & 0.809 & 4 & 6 \\
\hline Posttest Relaksasi otot progresif & 3.42 & 1.121 & 1 & 5 \\
\hline Pretest Alkupresur & 5.16 & 0.688 & 4 & 6 \\
\hline Posttest Akupresur & 3.11 & 1.197 & 0 & 5 \\
\hline
\end{tabular}

Berdasarkan tabel 3 dapat dilihat nilai rata-rata intensitas nyeri pada kelompok terapi relaksasi otot progresif sebelum diberi intervensi sebesar 4.89 poin dan sesudah diberi intervensi sebesar 3.42 poin, dimana mengalami penurunan sebesar 1.47 poin. Sedangkan pada kelompok terapi akupresur rata-rata intensitas nyeri sebelum diberi intervensi sebesar 5.16 poin dan sesudah diberi intervensi sebesar 3.11 poin yang mengalami penurunan sebesar 2.05 poin.Sehingga dapat disimpulkan bahwa penurunan intensitas nyeri dismenore pada kelompok terapi akupresur lebih tinggi dari 
pada kelompok terapi relaksasi otot progresif.

\section{PEMBAHASAN}

\section{Karakteristik responden berdasarkan usia}

Berdasarkan hasil penelitian yang telah dilakukan pada mahasiswi Fakultas Keperawatan Universitas Riau didapatkan dari 38 orang responden, sebagian besar responden berusia 21-23 tahun. Hal ini disebabkan karena pada umur tersebut terjadi proses optimalisasi fungsi saraf rahim sehingga sekresi prostaglandin meningkat yang akhirnya timbul rasa sakit ketika haid.

Hasil ini diperkuat dengan penelitian yang dilakukan oleh Rohima (2016) dengan hasil penelitiannya menunjukkan bahwa umur adalah salah satu faktor yang mempengaruhi kejadian dismenore dan respon seseorang terhadap nyeri. Menurut Departemen Kesehatan (2009) umur responden dalam penelitian ini termasuk dalam kategori remaja akhir yang mana pada masa ini terjadi peningkatan rasa nyeri sampai mencapai usia 30-35 tahun dan nyeri akan berkurang dengan sendirinya, hal ini disebabkan karena adanya kemunduran saraf rahim akibat penuaan, serta umur remaja akhir ini termasuk salah satu umur yang paling sering mengalami dismenore karena pada masa itu terjadi puncak rasa nyeri yang juga beresiko menderita dismenore primer (Reeder et al., 2013).

\section{Karakteristik responden berdasarkan suku}

Responden dalam penelitian ini berasal dari berbagai suku yaitu suku Melayu, Minang, Batak, Jawa, dan Nias dimana suku Melayu dan Minang yang terbanyak $36.8 \%$ dan $36.8 \%$. Hal ini terjadi karena lokasi penelitian merupakan daerah yang dominan penduduk yang memiliki suku Melayu dan Minang sehingga kebanyakan mahasiswi yang ada di Fakultas Keperawatan Universitas Riau adalah suku Melayu dan Minang.
Hasil penelitian ini sesuai dengan data Badan Pusat Statistik Provinsi Riau (2010) yakni suku Melayu merupakan salah satu penduduk terbesar dengan komposisi sebesar $37.74 \%$ dari seluruh penduduk di Provinsi Riau dan suku Minang umumnya banyak bertempat tinggal pada kawasan perkotaan seperti Pekanbaru, Dumai dan Kampar, sedangkan suku Jawa, Sunda dan Nias pada umumnya banyak berada pada kawasan transmigran.

\section{Karakteristik responden berdasarkan siklus haid}

Selain itu, secara keseluruhan siklus haid dari 38 responden didapatkan memiliki siklus haid yang normal dengan rentang 2435 hari sebesar $100 \%$. Dalam penelitian ini siklus haid tidak ada hubungan sebab akibat dengan dismenore, hal ini kemungkinan terjadi disebabkan oleh kelemahan peneliti dalam penyusunan pertanyaan variabel pada lembar observasi, dimana responden bisa saja tidak tahu cara menghitung siklus haid yang benar, sehingga responden mengisi lembar observasi berdasarkan pengetahuannya saja.

\section{Karakteristik responden berdasarkan} usiamenarche dan usia dismenore

Sebagian besar responden dalam penelitian ini mengalami menarche pada usia kurang dari 12 tahun $63.2 \%$ dan mengalami dismenore yaitu rata-rata terjadi sekitar 6-12 bulan setelah menarche. Hal ini sejalan dengan teori Sukarni \& Wahyu (2013) bahwa dismenore primer terjadi beberapa waktu setelah 6-12 bulan haid pertama. Hal ini diperkuat dengan penelitian yang dilakukan Herawati (2017) bahwa menarche pada usia lebih awal merupakan faktor risiko yang berpengaruh terhadap kejadian dismenore, dimana alat reproduksinya belum berkembang secara optimal dan masih terjadi penyempitan pada leher Rahim. Hal ini diperkuat dengan teori Progestian (2010) menyatakan bahwa dismenore pada umumnya akan timbul setelah 1-2 tahun setelah menarche. 
Adapun cara responden dalam menangani dismenore mayoritas dengan melakukan kompres air dingin dan tidur dengan masing-masing sebesar $31.5 \%$, dimana hal ini sesuai dengan penelitian yang dilakukan oleh Oktasari, Misrawati dan Utami (2014) dengan hasil akhir penelitian menyatakan bahwa kompres air dingin lebih efektif daripada kompres air hangat.

\section{Perbandingan intensitas nyeri sesudah intervensi pada kedua kelompok}

Berdasarkan hasil penelitian ini dapat dilihat perbandingan keefektifitasan dari kedua perlakuan intervensi terhadap intensitas nyeri pada penderita dismenore.

Hasil uji mann whitney untuk perbandingan intensitas nyeri sesudah intervensi pada kelompok terapi relaksasi otot progresif dan akupresur menunjukkan $p$-value $0.001<\alpha(0.05)$, artinya terdapat perbedaan yang signifikan antara terapi relaksasi otot progresif dan akupresur terhadap penurunan dismenore.

Berdasarkan hasil uji statistik tersebut diketahui ada perbandingan penurunan rata-rata intensitas nyeri dismenore pada kelompok terapi relaksasi otot progresif dan akupresur, dimana mean rank penurunan intensitas nyeri pada kelompok terapi relaksasi otot progresif sebesar 15.34 dan akupresur sebesar 23.66, sehingga dapat dilihat perbandingan mean rank intensitas nyeri pada kelompok terapi akupresur lebih signifikan menurunkan nyeri dismenore.

Terapi akupresur dalam menurunkan intensitas nyeri dismenore terletak pada penekanannya yang memiliki efek serupa dengan endorphin, dimana endorphin sendiri merupakan pembunuh rasa nyeri yang dihasilkan secara alami oleh tubuh, dengan cara kerja endorphin sama dengan cara kerja obat opiate seperti morfin yang mempengaruhi daerah-daerah pengindra nyeri di otak (Ody, 2008). Sedangkan pada terapi relaksasi otot progresif tidak mempunyai efek yang sama dengan akupresur, dimana terapi relaksasi otot progresif dalam menurunkan intensitas nyeri dismenorenya dilakukan dengan menekan saraf simpatis sehingga dapat mengurangi rasa tegang yang dialami oleh individu secara timbal balik yang menimbulkan counter conditioning (penghilangan), yang dapat menurunkan ketegangan dan menimbulkan rasa nyaman.

Hasil penelitian ini sejalan dengan penelitian yang dilakukan oleh Natalia, Komalaningsih, Syarief, Wirakusumah dan Suardi (2020) dengan hasil akhir menunjukkan bahwa terapi akupresur lebih efektif 15 kali menurunkan intensitas nyeri haid (dismenore) primer dibandingkan teknik relaksasi nafas dalam.

Terapi relaksasi otot progresif dan terapi akupresur sama - sama efektif dalam menurunkan intensitas nyeri dismenore, namun dengan proses yang berbeda secara fisiologis. Selain itu kedua terapi ini mudah untuk dilakukan, dimana instruksi yang digunakan menggunakan bahasa sederhana sehingga mudah untuk dipahami serta tindakan pada kedua terapi dapat dilakukan tanpa bantuan dari orang lain, selain itu peralatan yang digunakan mudah untuk didapatkan di lingkungan sekitar.

Terapi relaksasi otot progresif dan akupresur dalam menurunkan intensitas nyeri terdapat beberapa bias dalam proses pengumpulan data dan pelaksanaan intervensi dalam penelitian ini, seperti dari segi asupan nutrisi setiap responden yang berbeda, tempat pelaksanaan intervensi pada tiap-tiap responden yang berbeda (karena dilakukan pada tempat tinggal masing-masing responden), proses pemahaman materi intervensi setiap responden yang berbeda, serta jumlah tindakan terapi dari setiap kelompok terapi yang berbeda-beda, dimana terapi relaksasi otot progresif memiliki 14 tindakan yang harus dilakukan sedangkan terapi akupresur memiliki 2 tindakan, sehingga membuat responden pada kelompok terapi akupresur lebih signifikan dalam menurunkan intensitas nyeri dismenore dibandingkan kelompok terapi relaksasi otot progresif. 
Perbandingan intensitas nyeri sebelum dan sesudah intervensi

Menurut Apriyanti dan Pratiwi (2016) Dismenore adalah nyeri berlebihan saat haid yang terjadi akibat kontraksi uterus yang tidak terkoordinasi, hal ini disebabkan karena peningkatan produksi prostaglandin yang dilepas kedalam peredaran darah. Salah satu cara untuk mengatasi dismenore adalah dengan cara terapi relaksasi otot progresif dan akupresur.

Hasil penelitian ini sesuai dengan penelitian Thaharah (2020) dengan hasil akhir menunjukkan bahwa responden mengalami penurunan intensitas nyeri dismenore sebesar 2 poin setelah dilakukan terapi relaksasi otot progresif pada Mahasiswi Poltekkkes Kemenkes Riau. Perubahan intensitas nyeri dismenore yang dirasakan oleh responden selain karena produksi opiate endogen yang meningkat, juga dapat disebabkan oleh distraksi (memusatkan perhatian) pada suatu aktivitas otot yang tegang sehingga responden harus berfokus pada setiap gerakan yang dilakukan sehingga mengalihkan perhatian responden dari nyeri yang dirasakan.

Tidak hanya terapi relaksasi otot progresif saja yang dapat menurunkan intensitas nyeri dismenore, tetapi dari hasil penelitian ini juga menunjukkan bahwa adanya penurunan intensitas nyeri dismenore yang signifikan dengan menggunakan terapi akupresur. Pernyataan ini sesuai dengan penelitian yang dilakukan Hasanah et al, (2020) dengan hasil akhir bahwa terapi akupresur pada tiga titik kombinasi yaitu LR3, Li4 dan titik Yintang dapat menurunkan intensitas nyeri dismenore sebesar 3.13 poin.

Berdasarkan hasil penelitian terhadap 19 responden sebagai kelompok relaksasi otot progresif dan 19 responden sebagai kelompok akupresur, didapatkan bahwa nilai rata-rata intensitas nyeri sebelum diberikan intervensi pada kelompok relaksasi otot progresif adalah 4.89 dan setelah diberikan intervensi 3.42, sedangkan rata-rata intensitas nyeri dismenore sebelum diberikan intervensi pada kelompok akupresur adalah 5.16 dan setelah diberikan intervensi 3.11. Rata-rata intensitas nyeri pada kelompok terapi relaksasi otot progresif mengalami penurunan sebanyak 1.47 poin, sedangkan rata-rata intensitas nyeri pada kelompok terapi akupresur juga mengalami penurunan sebanyak 2.05 poin.

Hasil penelitian rata-rata intensitas nyeri dismenore pada kelompok terapi relaksasi otot progresif mengalami penurunan.Hal ini sesuai dengan penelitian Nurdin (2013) dengan hasil akhir menunjukkan adanya penurunan intensitas nyeri setelah pemberian terapi relaksasi otot progresif dengan $p$-value $0.001<\alpha 0.05$, karena teknik relaksasi otot progresif dapat merilekskan otot dan saraf yang tegang akibat kontraksi dinding rahim pada saat haid.

Hal ini diperkuat oleh Kustriyanti \& Boediarsih (2018) yang mengatakan bahwa relaksasi otot progresif bekerja menurunkan dengan mekanisme distraksi (memusatkan perhatian) pada suatu aktivitas otot dengan mengidentifikasi otot yang tegang sehingga responden harus berfokus pada setiap gerakan yang dilakukan sehingga mengalihkan perhatian responden dari nyeri yang dirasakan dan kemudian menurunkan persepsi nyeri yang dirasakan responden. Rasa nyaman mulai dirasakan saat responden melakukan gerakan yang ke 12.Gerakan ke 12 ini merupakan suatu relaksasi pernafasan yang dilakukan untuk mengatasi dari nyeri yang dirasakan.

Tidak hanya kelompok terapi relaksasi otot progresif saja, tetapi kelompok terapi akupresur juga mengalami penurunan yang sangat signifikan. Hal ini diperkuat oleh teori Master (2020) yang mengatakan bahwa akupresur dapat meningkatkan kadar beta endorphin. Hal ini juga sejalan dengan teori Widyaningrum (2013) dimana akupresur meningkatkan kadar endorphin yang berguna sebagai pereda nyeri yang diproduksi tubuh dalam darah dan opiad peptide endogeneus 
didalam susunan syaraf pusat, dimana jaringan syaraf akan memberi stimulus pada sistem endokrin untuk melepaskan endokrin sesuai kebutuhan tubuh dan diharapkan dapat menurunkan rasa nyeri saat haid.

\section{KESIMPULAN}

Hasil penelitian menunjukkan bahwa karakteristik umur responden mayoritas yang mengalami dismenore adalah 21-23 tahun (71.1\%), suku responden pada kedua kelompok mayoritas adalah suku Melayu dan suku Minang yang jumlahnya sama banyak masing-masing sebesar $36.8 \%$, dimana secara keseluruhan responden dalam penelitian ini memiliki siklus haid dalam rentang yang normal sebesar $100 \%$, serta sebagian besar responden dalam penelitian ini mengalami menarche pada usia kurang dari 12 tahun $63.2 \%$ dan mengalami dismenore yaitu rata-rata terjadi sekitar 6-12 bulan setelah menarche sebesar $38.2 \%$.

Rata-rata intensitas nyeri sebelum dan sesudah diberi perlakuan pada kedua kelompok mengalami penurunan yaitu pada kelompok terapi relaksasi otot progresif 1.47 poin dan kelompok terapi akupresur dengan 2.05 poin serta $p$-value $0,000<\alpha$ 0,05 pada kedua kelompok sehingga dapat disimpulkan ada perbedaan yang signifikan sebelum dan sesudah dilakukan intervensi pada kelompok terapi relaksasi otot progresif dan kelompok terapi akupresur.

Perbandingan sesudah dilakukan intervensi antara kelompok terapi relaksasi otot progresif dan kelompok terapi akupresur dengan p-value $0.001<\alpha 0.05$ sehingga dapat disimpulkan Ho ditolak.Hal ini berarti terdapat perbedaan yang signifikan antara terapi relaksasi otot progresif dan akupresur terhadap penurunan dismenore. Perbandingan mean rank yang didapat setelah dilakukan intervensi pada kelompok terapi akupresur lebih besar yaitu 23.66 dibandingkan kelompok terapi relaksasi otot progresif sebesar 15.34. Oleh karena itu terapi relaksasi otot progresif dan akupresur sama sama efektif dalam menurunkan intensitas nyeri dismenore, tetapi terapi akupresur lebih signifikan dalam menurunkan intensitas nyeri dismenore.

\section{UCAPAN TERIMAKASIH}

Penulis mengucapkan terimakasih untuk semua pihak yang telah membantu peneliti dalam membuat skripsi penelitian ini.

\section{DAFTAR PUSTAKA}

Alamsyah, I. (2009). Cara lebih mudah menemukan titik terapi acupoint. Jakarta:Isa

Akbar, I., Eka, D., \& Afriyanti, E. (2012). Pengaruh Relaksasi Otot Progresif terhadap Penurunan Dismenore pada Mahasiswi A 2012 Fakultas Keperawatan Unand. 2004. https://www.ejurnal.com/2015/12/pengaruhrelaksasi-otot-progresif.html

Anurogo, D., \& Wulandari, A. (2011). Cara jitu mengatasi nyeri haid. Yogyakarta: Andi.

Ayu, D, C. (2019). Buku ajar kesehatan reproduksi remaja dan wanita. Yogyakarta: PT Pustaka Baru.

BPS Provinsi Riau. Hasil sensus penduduk 2010

https://riau.bps.go.id/publications/20 10/11/cf5dcfe20e1 eb082593dc9bc/ri au-dalam-angka-2010.html

Dewi, P., Patimah. S., \& Khairiyah (2018). Pengaruh relaksasi otot progresif terhadap penurunan nyeri punggung bagian bawah ibu hamil trimester III. Midwife Journal. https://media.neliti.com/media/publi cations/267044-pengaruh-relaksasiotot-progresif-terhadap40eb2c95.pdf

Friska, M., Utami, S., \& Rahmalia, S. (2016). Efektivitas yoga terhadap nyeri dismenorea pada remaja. JOM Unri. https://jom.unri.ac.id/index.php/JO MPSIK/article/view/8291

Hasanuddin. (2019). Pengaruh teknik relaksasi nafas dalam terhadap 
dismenorea. Journal Of Midwifery, 31-37.

http://pasca.unhas.ac.id/ojs/index.ph $\mathrm{p} / \mathrm{hjm} /$ article/view/1791

Herawati, R. (2017). Faktor faktor yang mempengaruhi kejadian nyeri haid pada siswi madrasah aliyah negeri pasir pangaraian. 161-172.

https://e-

journal.upp.ac.id/index.php/akbd/art icle/view/1382

Hasanah, O., Lestari, W., Novayelinda, R., \& Deli, H. (n.d.). Efektifitas Combo Accupresure Point Pada Fase Menstruasi Terhadap Dismenore https://www.onlinejournal.unja.ac.id/JINI/article/view/ 9226da Remaja.( Konishi ,.... 1, 111.

Iwan, R. W., \& Hartono. (2012). Akupresur untuk berbagai penyakit. Yogyakarta: Andi

Julianti. Hasanah, O. \& Erwin. (2020). Efektivitas akupresur terhadap dismenore pada remaja putri. JOM PSIK, 1(2). https://media.neliti.com/media/publi cations/188169-ID-efektifitasakupresur-terhadap-dismenore-pdf

Ody, P. (2008). Pengobatan Praktis Dari Cina. Jakarta: Esensi.

Oktasari, G., Utami, G. T., Studi, P., Keperawatan, I., \& Riau, U. (n.d.). Perbandingan efektivitas kompres hangat dan kompres dingin terhadap penurunan dismenorea pada remaja putri. 1-8. https://www.neliti.com/publications/ 185541/perbandingan-efektivitaskompres-hangat-dan-kompresdingin-terhadap-penurunan.

Koniak-Griffin, R. M. (2011). Keperawatan Maternitas. Jakarta: EGC.

Kustriyanti, D., \& Boediarsih. (2018). Terapi Relaksasi Otot Progresif Untuk Dismenorea. University Research Colloqium, 1-8. https://www.repository.ureco.org

Lemone, Burke, K., \& Bauldoff, G. (2016). Keperawatan Medikal Bedah.
Jakarta: EGC.

Master, K. (2020). Self Healing Therapy Menggunakan Akupuntur Dengan Jari Tangan. PT. Tangga Pustaka.

Natalia, W., Komalaningsih, S., Syarief, O., Wirakusumah, F., \& Suardi, A. (2020). Perbandingan efektivitas terapi akupresur sanyinjiaou point dengan teknik relaksasi nafas dalam untuk menurunkan nyeri menstruasi pada remaja di pesantren asshiddiqiyah 3 karawang. JSK, 5, 123-128.

https://jom.unri.ac.id/index.php/JO

MPSIK/article/view/8291.

Nurdin, S. Kiling, M. Rottie, J. (2013). Pengaruh teknik relaksasi terhadap intensitas nyeri pada pasien post operasi fraktur. ejournal keperawatan.

Pavithra, B., Sanggeetha, A., Anuja, A.V., Doss, S. S., Thanalakshmi, J. \& Vijayalakshmi (2020). Prevalence of menstrual symptoms and primary dysmenorrhea among medical undergraduate in south indian population. International Journal Of Research In Pharmaceutical Sciences, 11, 1348-1351.

https://pharmascope.org/ijrps/issue/v iew/45

Putinah. (2019). Penatalaksanaan kejadian dismenorea berdasarkan pengetahuan dan sikap mahasiswi. Babul Ilmi Jurnal Ilmiah Multi Science Kesehatan, 11, 53-62.

http://jurnal.stikes-aisyiyahpalembang.ac.id/JINI/article/view92 23

Putri. (2012). Kejadian dan Manajemen Dismenorea Pada Remaja Putri Di

Kecamatan Bangko Kabupaten Rokan Hilir.

https://www.pustaka.htp.ac.id

Radyanto Iwan Widya Hartono. (2012). Akupresur Untuk Berbagai Penyakit. Andi Publisher.

Ratnawati, A. (2018). Asuhan Keperawatan Pada Pasien Dengan Gangguan 
Sistem Reproduksi. Yogyakarta: PT. Pustaka Baru.

Ridwan, M. \& Herlina, H. (2015). Metode akupresur untuk meredakan nyeri. Jurnal Kesehatan Metro Sai Wawai. https://ejurnal.poltekkes-

tjk.ac.id/index.php/JKM/article/view $/ 170$.

Rohima, \& Ulya. (2016). Faktor risiko dismenore primer pada wanita usia subur di Kelurahan Ploso Kecamatan Tambaksari Surabaya. Jurnal berkala epidemiologi. https://www.researchgate.net/public ations/313962393

Rosyida, D. A. (2019). buku ajar kesehatan reproduksi remaja dan wanita. Yogyakarta: PT. Pustaka Baru.

Rustam, E. (2013). Gambaran pengetahuan remaja puteri terhadap nyeri haid (dismenore) dan cara penanggulangannya. https://jurnal.fk.unand.ac.id

Sukarni, I. K., \& Wahyu. (2013). Buku ajar keperawatan maternitas. Yogyakarta: Nuha Medika.

Thaharah, A. (2020). Pengaruh efektivitas teknik relaksasi otot progresif terhadap penurunan nyeri dismenorea pada mahasiswi poltekkes kemenkes riau http://repository.pkr.ac.id/1363/.

Wahyu, S. (2013). Buku ajar keperawatan maternitas. Nuha Medika.

Yuli Handayani, E. dkk. (2014). Faktor Faktor Yang Berhubungan Dengan Nyeri Menstruasi (Dismenorea) Pada Remaja Putri Di Beberapa SMA Di Kabupaten Rokan Hulu. Jurnal Maternity and Neonatal, 1(4), 161-171 https://ejournal.upp.ac.id/index.php/akbd/art icle/view/1077.

Wulandari, A., hasanah, O., \& Woferst, R. (2018). Gambaran kejadian dan manajemen dismenore pada remaja putri di Kecamatan Lima Puluh Kota Pekanbaru. JOM FKP.
https://jom.unri.ac.id/index.php/JO MPSIK/article/view/21161 